\title{
Fabrication, characterization and electrochemical properties of porous palladium bulk samples with high porosity and hierarchical pore structure
}

\author{
Qingquan Kong a, Wei Feng a,*, Xiaodong Zhu a , Jing Zhang b, Chenghua Sun c,\# \\ a School of Mechanical Engineering, Chengdu University, Chengdu 610106, Sichuan, China \\ b School of Materials Science and Engineering, Sichuan University, Chengdu 610065, Sichuan, China \\ c School of Chemistry, Faculty of Science, Monash University, Clayton, VIC 3800, Australia
}

\section{A R T I C L E I N F O}

\section{Article history:}

Received 30 November 2016

Accepted 5 January 2017

Published 5 June 2017

Keywords:

Palladium

Hierarchical porous structure

Electrocatalysis

Ethanol oxidation
Spark plasma sintering

\begin{abstract}
A B S T R A C T
In the present study, porous bulk palladium samples were prepared by sodium chloride salt powder spacer incorporation and removal combined with dealloying. The obtained porous Pd bulks were characterized by X-ray diffraction, field-emission scanning electron microscopy and $\mathrm{N}_{2}$ adsorption isotherm measurements. The prepared porous Pd bulk samples showed a hierarchical pore structure, a high porosity of $\sim 88 \%$, a high surface area of $\sim 54 \mathrm{~m}^{2} / \mathrm{g}$, and a compression strength of $\sim 0.5$ $\mathrm{MPa}$. Electrochemical measurements were performed to evaluate the electrocatalytic properties of the porous Pd bulk samples, revealing their effectiveness for ethanol oxidation.
\end{abstract}

(C) 2017, Dalian Institute of Chemical Physics, Chinese Academy of Sciences. Published by Elsevier B.V. All rights reserved.

\section{Introduction}

Palladium materials are widely used in hydrogen storage and separation applications [1,2], catalysts [3-6], and sensors [7-9]. In particular, supported Pd shows excellent performance in the electrochemical oxidation of ethanol and methanol and combustion of methane [3,6,10]. Metal nanoparticles of conventional Pd-supported catalysts are often unstable in many applications and aggregate, resulting in degradation of the catalysis properties [11]. Compared with typical Pd foil, conventional supported Pd and powder samples [12-14], porous Pd materials have many advantages such as a high surface area, a connected pore channel network, and a structure which is sta- ble to the aggregation effects that occur in powders [1,15]. In addition, bulk porous Pd has applications in a broad range of fields, and is considered a promising candidate material for functional devices.

Recently, considerable research efforts have focused on fabricating porous Pd materials with high porosity, hierarchical pore structures and large surface areas. Hierarchical porous structures have been shown to have more effective electrocatalytic properties toward the oxygen reduction reaction compared with monolithic nanoporous structures [16-18]. Powder sintering routes using spacer materials such as sodium chloride have been reported by Li et al. [19]. The porosity of the prepared porous materials can be easily adjusted by changing the

\footnotetext{
* Corresponding author. Tel/Fax: +86-28-84616169; E-mail: 50919808@qq.com

\# Corresponding author. Tel: +61-3-99029916; Fax: +61-3-99054597; E-mail: Chenghua.Sun@monash.edu

This work was supported by the National Natural Science Foundation of China (11572057) and the School Foundation of Chengdu University (2080516030).

DOI: 10.1016/S1872-2067(17)62780-3| http://www.sciencedirect.com/science/journal/18722067 | Chin. J. Catal., Vol. 38, No. 6, June 2017
} 
amount of spacer material added. However, the surface area of the resultant porous $\mathrm{Pd}$ is relatively low.

Dealloying methods have also been used as a simple way to form nanoporous metals [20,21]. Nanoporous Pd with connected pore/ligaments and a large surface area has been successfully fabricated by dealloying techniques [22,23]. However, is difficult to fulfill key requirements for high performance porous Pd materials, such as a bulk (millimeter-sized) self-supporting hierarchical pore structure, with the use of this method [16,17]. Spark plasma sintering (SPS) has been used extensively and shows clear benefits over conventional methods $[24,25]$. In previous studies, mechanical alloying and SPS methods have been used to fabricate $\mathrm{CuAl}$ and PdAl alloys $[26,27]$. Bulk nanoporous metallic materials have been successfully prepared from the resultant SPS sintering alloy precursors by dealloying. Thus, we expect that, the use of soluble salts, such as $\mathrm{NaCl}$, as spacer materials in the SPS sintering process combined with chemical dealloying, may allow for bulk hierarchical porous metallic materials to be obtained.

Here, we present a novel processing technique that allows for fabrication of porous Pd bulk samples with a hierarchical self-supported porous structure (millimeter- and nano-sized), which has high porosity. Moreover, the electrochemical properties of the prepared porous Pd bulk samples were also studied.

\section{Experimental}

PdAl mechanical alloying (MA) powder was obtained by ball milling of $\mathrm{Al}(>99.9 \%, \sim 2 \mu \mathrm{m}, \mathrm{ST}$ NANO, China) and Pd (>99.95\%, Northwest Institute for Non-ferrous Metal Research, China) with a composition of $\mathrm{Al}-20$ atom $\% \mathrm{Pd}$ under vacuum. The PdAl alloy composites were prepared by spark plasma sintering (SPS) of the PdAl MA powder with various amounts of $\mathrm{NaCl}$ powder added $(\sim 50 \mu \mathrm{m}, 10$ vol.\%, 20 vol.\%, 30 vol.\%, denoted as PA1, PA2, PA3, respectively). The power/salt mixtures were subjected to SPS sintering in a Dr SPS-1050 apparatus in a tungsten carbide mold. A sintering temperature of $600{ }^{\circ} \mathrm{C}$ and a pressure of $30 \mathrm{MPa}$ and a holding time of $30 \mathrm{~min}$ were chosen. The resultant $\mathrm{PdAl}$ alloy composites were wire cut and ground with $\mathrm{SiC}$ paper. The PdAl alloy composites were immersed in deionized water to extract the $\mathrm{NaCl}$ particles, and chemically etched in $0.5 \mathrm{~mol} / \mathrm{L} \mathrm{HCl}$ solutions at room temperature. The dealloyed samples were rinsed with ethanol and deionized water.

The samples were characterized with a field-emission scanning electron microscope (FE-SEM, Hitachi S4800) equipped with an X-ray energy spectrometer (EDS). X-ray diffraction (XRD) patterns were recorded by an X-ray diffractometer (DX-2000) with $\mathrm{Cu} K_{\alpha}$ radiation. The compressive strength tests were performed on an Instron mechanical testing machine (Instron 4302) with a crosshead speed of $0.5 \mathrm{~mm} / \mathrm{min}$. All specimens used in the compressive tests were cut to a size of 5 $\mathrm{mm} \times 5 \mathrm{~mm} \times 10 \mathrm{~mm}$. At least three specimens were tested for each sample. The specific surface areas of Pd samples were measured with an $\mathrm{N}_{2}$ adsorption apparatus. Electrochemical measurements were performed in a standard three-electrode cell (500 mL) using a electrochemical workstation (CHI660E) with a Pt plate electrode as a counter electrode and a saturated calomel electrode (SCE) or a $\mathrm{Hg} / \mathrm{HgO}$ reference electrode. The porous Pd bulk samples were used as the working electrode. Cyclic voltammetry was measured in $1 \mathrm{~mol} / \mathrm{L} \mathrm{H}_{2} \mathrm{SO}_{4}$ solution. The ethanol electro-oxidation performance was characterized in a mixture of $1.0 \mathrm{~mol} / \mathrm{L} \mathrm{KOH}$ with different concentrations of ethanol. The electrolytes were de-aerated by $\mathrm{N}_{2}$. Electrochemical experiments were performed at ambient temperature. The current density was calculated by reference to the geometric area of the work electrode

\section{Results and discussion}

\subsection{Characterization of the Pd alloy composite}

Fig. 1 shows the density of the Pd alloy composites. As the amount of added $\mathrm{NaCl}$ was increased from 10 vol.\% to 30 vol.\%, the density of the prepared PdAl composites decreased. The addition of more spacer may be beneficial for decreasing the density of the bulk; however, too much spacer may lead to formation of defects and even collapse of the structure. To obtain robust $\mathrm{PdAl}$ alloy composites, the amount of $\mathrm{NaCl}$ added should be maintained below 30 vol.\%. An XRD pattern of PA2 is shown in Fig. 2. The diffraction peaks could be assigned to $\mathrm{PdAl}_{3}, \mathrm{Al}$, and $\mathrm{NaCl}$, indicating that a PdAl alloy composite was successfully prepared. Notably the presence of the $\mathrm{NaCl}$ particles does not disrupt the formation of PdAl alloy. The mechanism of SPS remains unclear, despite several decades of study and development [25]. The presence of plasma during the SPS process has been realized as an important hypothesis $[28,29]$. However, experiments performed by Mukherjee et al. indicated that there is no plasma, sparking or arcing present during the SPS process. Joule heating effects and electromigration of point defects or other current effects are now considered to be the primary reason for enhanced sintering in conducting powders and thermal exchange in non-conductive powder [25,30,31]. Thus, only thermal exchange can take place between the PdAl mechanical alloying powders and $\mathrm{NaCl}$ particles, ensuring that

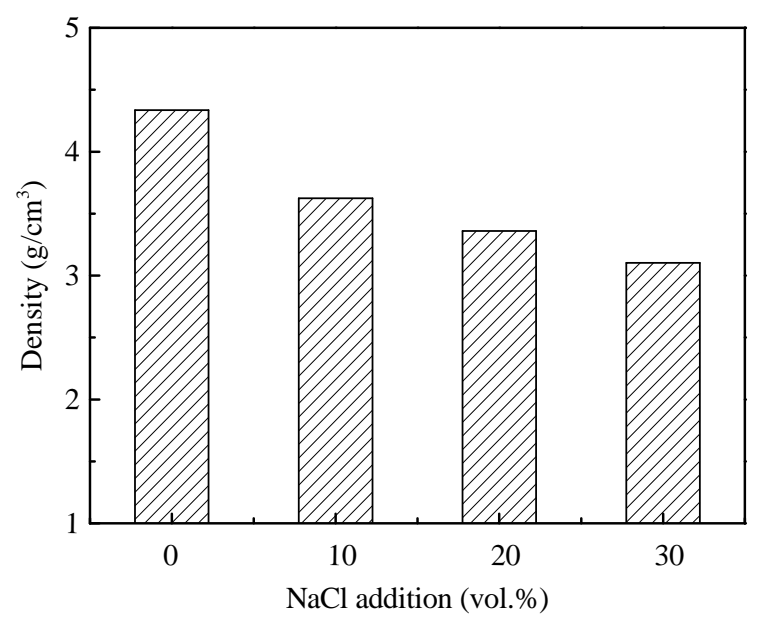

Fig. 1. Density of PdAl alloy composites as a function of the amount of added $\mathrm{NaCl}$. 


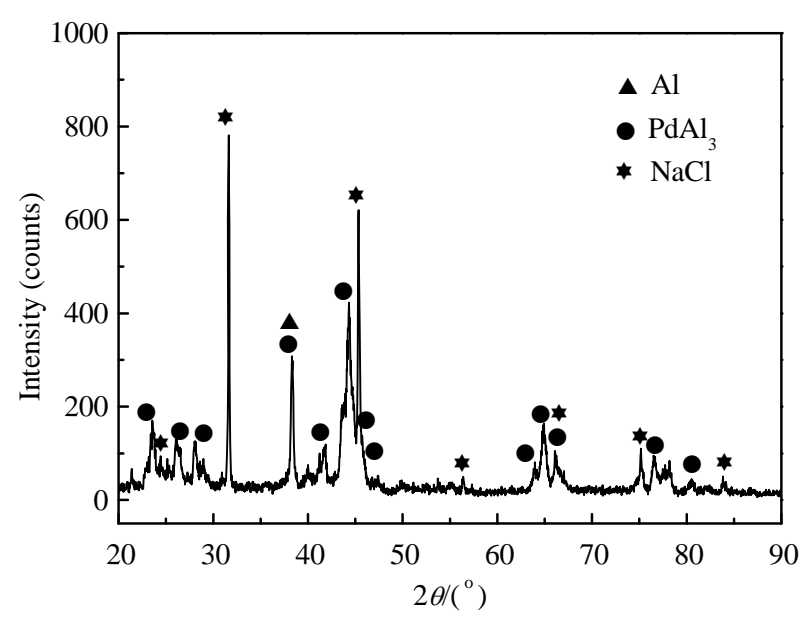

Fig. 2. XRD pattern of PdAl alloy composite (PA2).

the PdAl alloy phase forms at a lower sinter temperature with no impurity elements.

\subsection{Phase composition, microstructure and mechanical properties of porous Pd bulks}

Fig. 3 shows an XRD pattern of the dealloyed PA2. Only the $\mathrm{Pd}$ phase was detected after dealloying in $\mathrm{HCl}(0.5 \mathrm{~mol} / \mathrm{L})$. Both $\mathrm{PdAl}_{3}$ and $\mathrm{Al}$ were fully corroded by the $\mathrm{HCl}$ solution. The diffraction peak of $\mathrm{NaCl}$ was not detected in the dealloyed sample indicating complete removal of $\mathrm{NaCl}$.

FE-SEM images of the dealloyed samples are shown in Fig. 4 showing porous $\mathrm{Pd}$ bulk materials with a bimodal porous structure. Large pores of tens micrometers (Fig. 4(a), (c) and (e)) and small pores of a few nanometers (Fig. 4(b), (d) and (e)) can be observed. The large pores with an average size of $\sim 40$ $\mu \mathrm{m}$ originated from the removal of the $\mathrm{NaCl}$ spacer. These pores appear to be bar-shaped owing to a change in the shape of the NaCl particles during SPS sintering process under uniaxial pressure. The number of larger pores increased as amount of added $\mathrm{NaCl}$ was increased. High resolution SEM images revealed that the large channel walls had an open, bi-continuous interpenetrating ligament-channel structure with a fine liga-

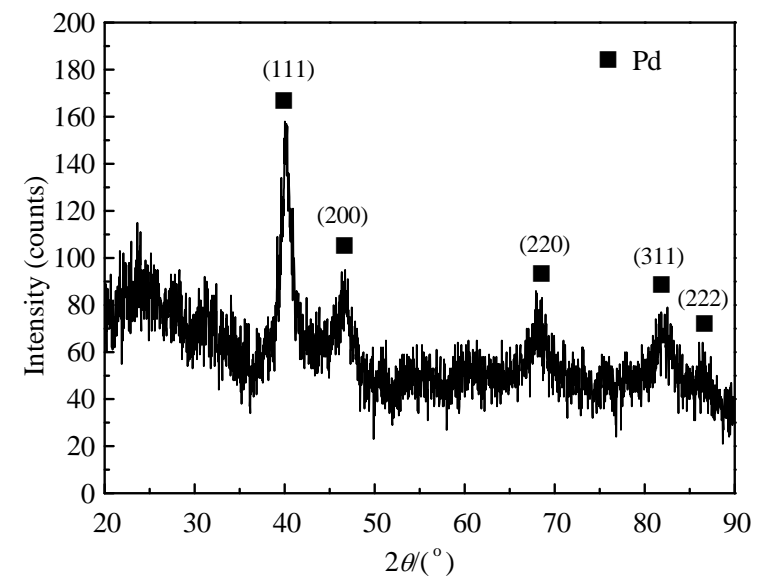

Fig. 3. XRD pattern of dealloyed PA2.
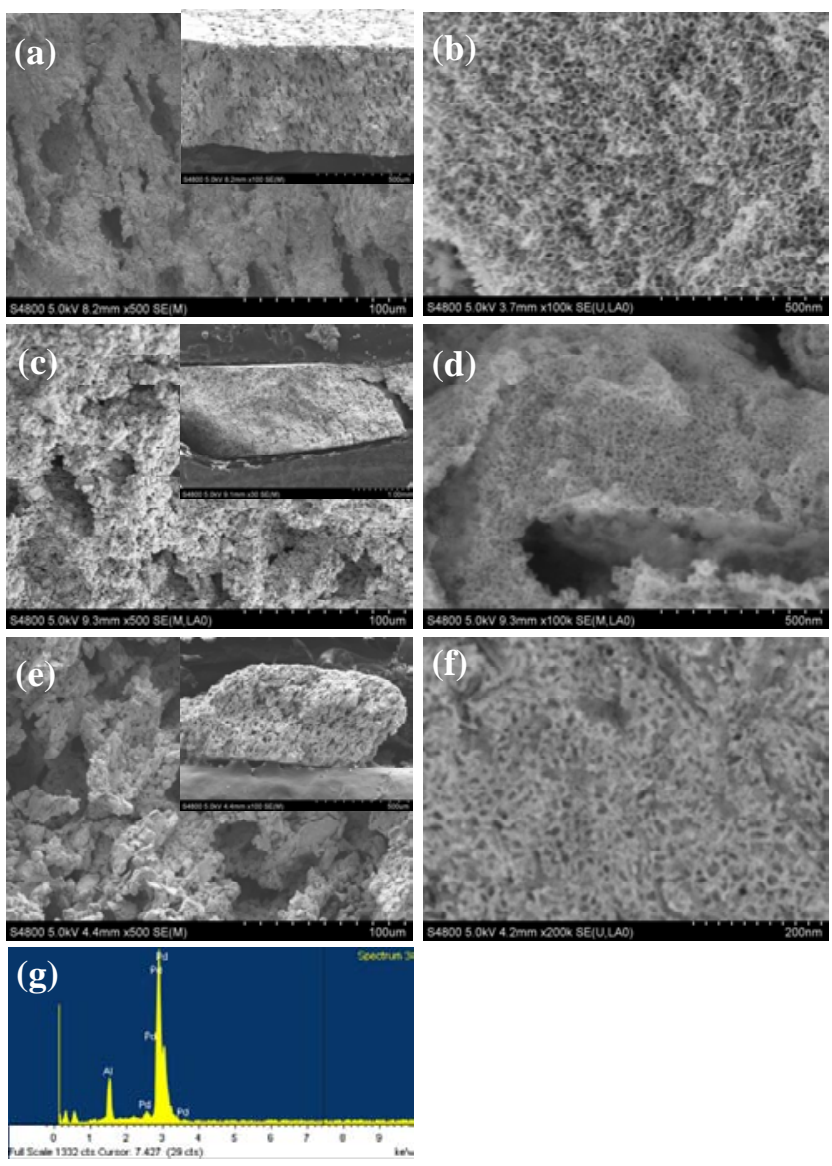

Fig. 4. FE-SEM images of dealloyed samples. (a, b) PA1; (c, d) PA2; (e, f) PA3; (g) EDS pattern of dealloyed PA2.

ment size of $\sim 10 \mathrm{~nm}$ (as shown in Fig. 4(b) and (d) and (f)). The insets in Fig. 4(a) and (c) indicate that a robust bulk structure was obtained. Conversely, the dealloyed PA3 showed collapse of the structure (inset of Fig. 4(e). Thus, to prepare robust porous $\mathrm{Pd}$ bulk, the amount of $\mathrm{NaCl}$ spacer added should be carefully controlled. The dealloyed PA2 was analyzed by EDS, as shown in Fig. 4(g), indicating the presence of Pd and a small amount of Al. Table 1 shows the density and porosity of the prepared porous Pd bulk samples. A robust porous Pd bulk sample with a low density of $\sim 1.41 \mathrm{~g} / \mathrm{cm}^{3}$ and a high porosity of $88 \%$ was prepared after chemical dealloying of PA2.

Compression properties of the resultant porous $\mathrm{Pd}$ bulk samples were tested. Fig. 5 shows a strain-stress curve of the porous Pd bulk sample prepared by dealloying of PA2. The maximum compressive strength was $\sim 0.5 \mathrm{MPa}$. The inset in Fig. 5 shows photographs of the porous Pd bulk sample before

Table 1

Density, porosity, and surface area of porous Pd bulk samples.

\begin{tabular}{lcccc}
\hline Sample & $\begin{array}{c}\text { Dealloying } \\
\text { solution }\end{array}$ & $\begin{array}{c}\text { Density } \\
\left(\mathrm{g} / \mathrm{cm}^{3}\right)\end{array}$ & $\begin{array}{c}\text { Porosity } \\
(\%)\end{array}$ & $\begin{array}{c}\text { Surface area } \\
\left(\mathrm{m}^{2} / \mathrm{g}\right)\end{array}$ \\
\hline PA & $0.5 \mathrm{~mol} / \mathrm{L} \mathrm{HCl}$ & 3.41 & $\sim 72 \%$ & $\sim 57$ \\
PA1 & & 2.53 & $\sim 80 \%$ & $\sim 56$ \\
PA2 & & 1.41 & $\sim 88 \%$ & $\sim 54$ \\
PA3 & & Collapse & - & - \\
\hline
\end{tabular}




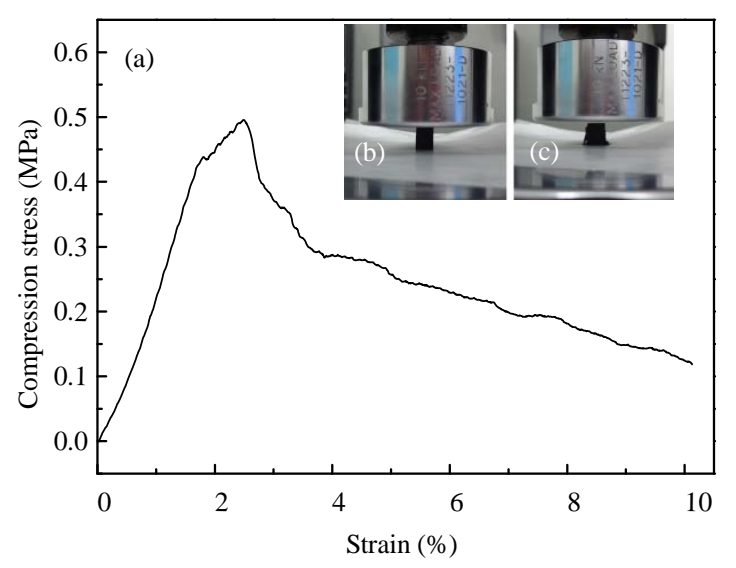

Fig. 5. Strain-stress curve (a) of porous Pd bulk sample prepared by dealloying of PA2, the insets are optical images of porous Pd bulk sample before (b) and after (c) compression test.

(b) and after (c) the compression test. Combined with the strain-stress curve, we can conclude that the main failure mechanism of the porous Pd bulk sample was brittle fracture. The failure was likely caused by defects generated in the bulk during the chemical dealloying process. A subsequent annealing step may reduce the number of cracks produced during the dealloying process and increase the material's strength and ductility [17].

The $\mathrm{N}_{2}$ isotherms of the porous Pd bulk samples are shown in Fig. 6. The samples prepared by dealloying of PA2 showed a high BET area of $\sim 54 \mathrm{~m}^{2} / \mathrm{g}$. The larger surface area of these porous Pd bulk samples can be attributed to the fine nanoporous structure. FE-SEM images of dealloyed PA1, PA2, and PA3 are shown in Fig. 4, revealing similar ligament/pore sizes of $\sim 10 \mathrm{~nm}$. Thus, the surface areas were consistent between samples (as shown in Table 1). The dealloyed PA2 bulk had a high porosity, a hierarchical pore structure, and good mechanical stability, which contributed to the large specific surface area. Consequently, this material was used as a candidate for investigation of the electrochemical properties. In the following section, we selected the porous Pd bulk sample prepared by dealloying of PA2 for further study.

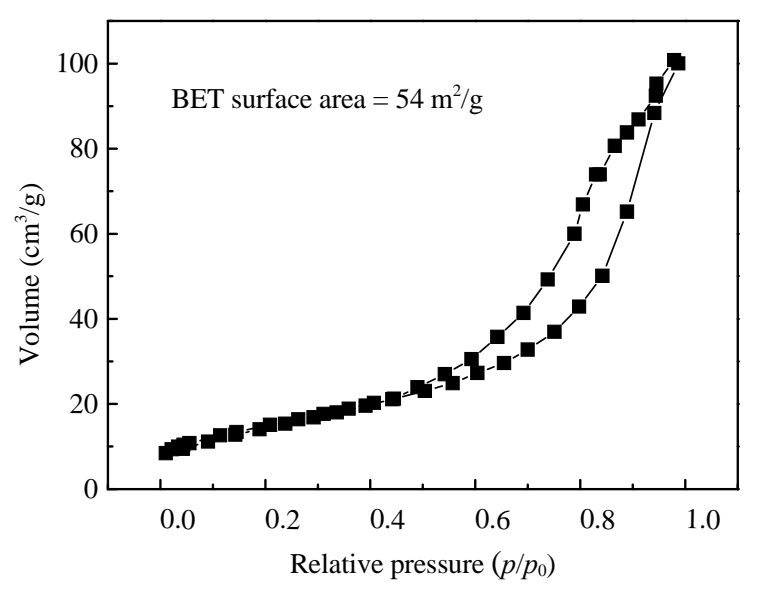

Fig. 6. $\mathrm{N}_{2}$ isotherm curves of porous Pd bulk sample prepared by dealloying of PA2.

\subsection{Catalytic performance}

Cyclic voltammetry (CV) curves of the porous Pd electrodes were measured in $1 \mathrm{~mol} / \mathrm{L}_{2} \mathrm{SO}_{4}$ solution, as shown in Fig. 7. Several distinct current peaks were present reflecting both oxidations and reductions. The broad oxidation peak in the forward scan arises from the formation of Pd surface oxide [32]. The reduction current peak at $0.315 \mathrm{~V}$ in the reverse scan indicates reduction of the Pd oxide. Notably this peak occurs at a lower current than that of a flat Pd electrode $(0.480 \mathrm{~V})$ [33]. A large reduction peak area was measured. Notably only one hydrogen adsorption peak can be observed in Fig. 7, which differs from the CV curves of previously reported $\mathrm{Pd}$ nanostructures that include two hydrogen adsorption peaks [34]. The unique hierarchical pore structure of the porous Pd bulk sample may explain this difference; however, the exact mechanism operating in this system requires further study.

The electrochemical properties of our porous Pd materials toward ethanol oxidation were investigated. Fig. 8(a) shows the effects of scan rate on the CV curves of the porous Pd electrode toward ethanol oxidation. Typical ethanol electrochemical oxidation CV curves were found as shown in Fig. 8(a). The current peaks were observed in both the forward and reverse scan directions. The mechanism of this oxidation process has been studied in detail by Zhao' group [4]. Fig. 8(a) shows that the oxidation peak current density $j_{\mathrm{p}}$ and peak potential $E_{\mathrm{p}}$ of the forward scan increased as the potential scan rate was increased from 10 to $50 \mathrm{mV} / \mathrm{s}$. Fig. 8(b) shows a linear relationship between the square root of scan rate $\left(v^{1 / 2}\right)$ and peak current, which indicates that diffusion control was the main rate determining factor for the porous Pd electrode under alkali conditions [34,35].

The effects of ethanol concentration $(0.1-4 \mathrm{~mol} / \mathrm{L})$ on the electrochemical oxidation of ethanol by the porous Pd electrode are shown in Fig. 9. The oxidation current peak located in the forward scan is typically used to evaluate the catalytic activity of an active material [33,36]. From Fig. 9, the peak potential $E_{p}$ in the forward scan direction increased as the concentration of ethanol was increased, while the oxidation peak current density jp first increased and then decreased (inset of Fig. 9).

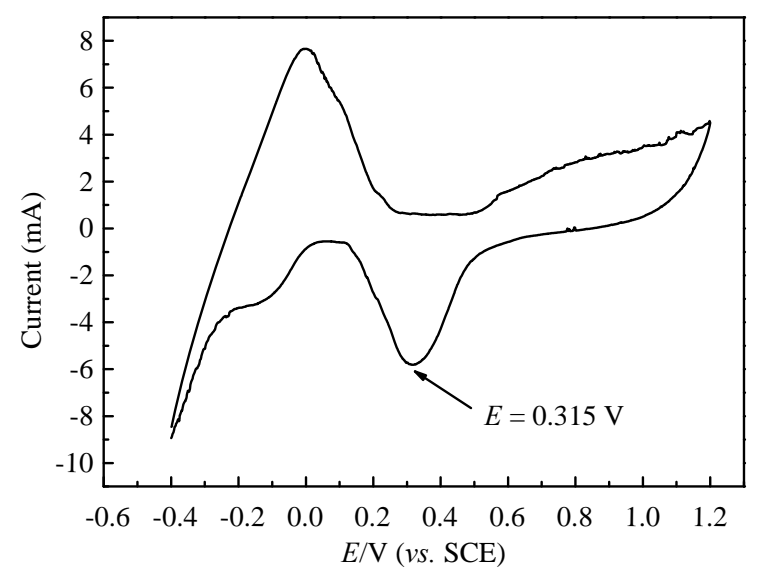

Fig. 7. CV curves of the porous Pd electrode in $\mathrm{H}_{2} \mathrm{SO}_{4}$ (1 mol/L) solution deaerated with Ar. Scan rate is $50 \mathrm{mV} / \mathrm{s}$. 

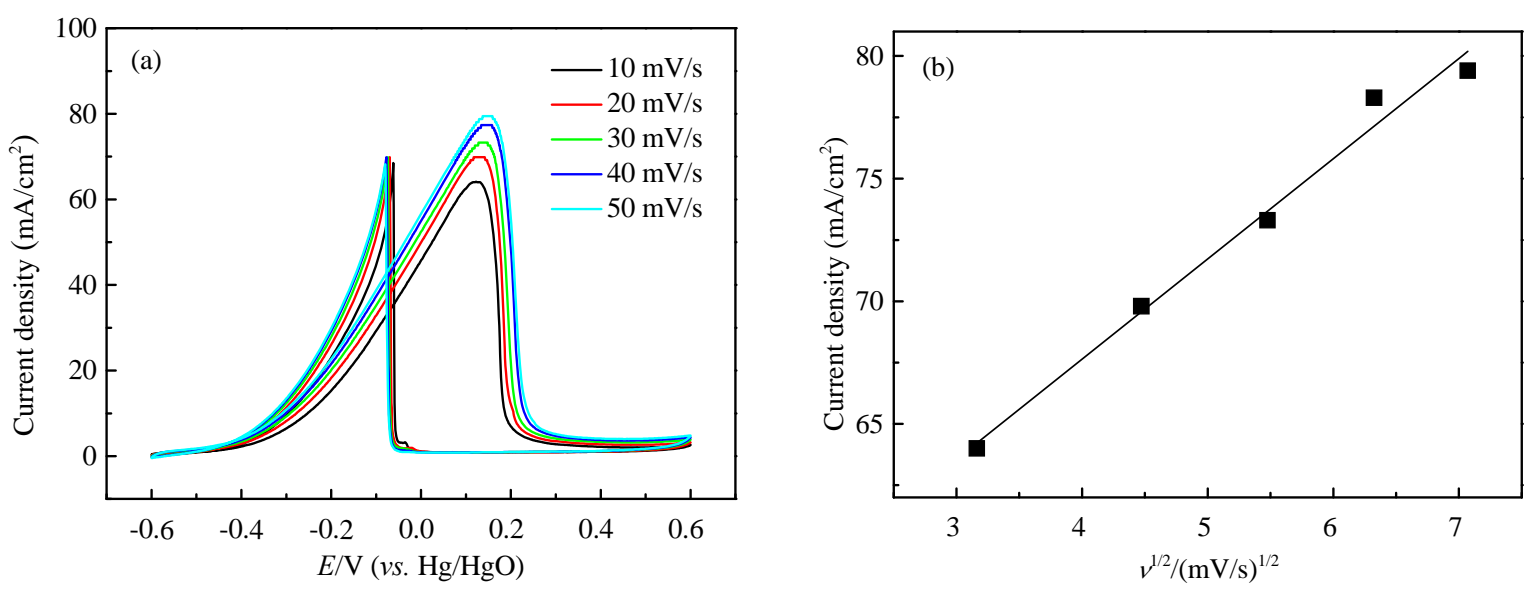

Fig. 8. CV curves of porous Pd electrode in the $1 \mathrm{~mol} / \mathrm{L} \mathrm{KOH}+0.8 \mathrm{~mol} / \mathrm{L}$ ethanol solution deaerated with Ar at different scan rates. (a) $j \sim E$, (b) $j \sim$ $v^{1 / 2}$.

This effect may be accounted for by competitive adsorption of ethanol and water at Pd sites [4]. As more Pd sites become occupied by ethanol at higher concentrations, the adsorption of water decreases. Excessive adsorption of ethanol and low water coverage on the porous Pd electrode leads to a decrease in the peak current. Thus, the concentration of ethanol should be optimized to ensure the most effective catalysis. The highest peak current of $\sim 120 \mathrm{~mA} / \mathrm{cm}^{2}$ in the forward scan was detected in the $1 \mathrm{~mol} / \mathrm{L} \mathrm{KOH}$ and $2 \mathrm{~mol} / \mathrm{L}$ ethanol solution. This value is larger than that measured for the plate Pd. The high porosity and hierarchical pore structure of our porous Pd electrode likely induced this superior ethanol oxidation ability. Compared with a flat Pd electrode, the nanoporous structure has a much higher active surface area, and the fluid resistance is also reduced by the presence of larger pores.

The catalytic stability of our porous Pd electrode was tested. As shown in Fig. 10, the peak current decrease slightly from $\sim 120$ to $\sim 110 \mathrm{~mA} / \mathrm{cm}^{2}$ after 50 cycles. The electrocatalytic activity of our porous Pd bulk samples towards ethanol was not much higher than that of some previous reports. In our case, the residual $\mathrm{Al}$ in the porous Pd bulk may have suppressed the

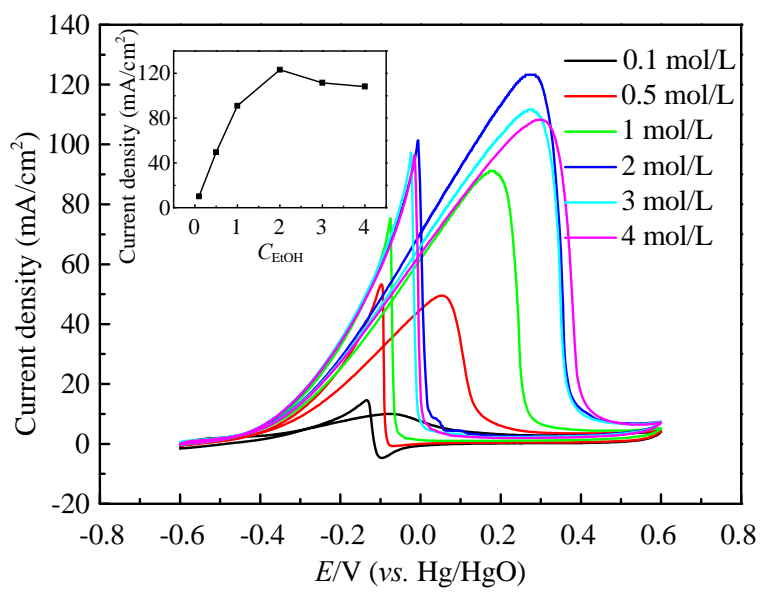

Fig. 9. $\mathrm{CV}$ curves of porous $\mathrm{Pd}$ electrode in $1 \mathrm{~mol} / \mathrm{L} \mathrm{KOH}$ and different concentrations of ethanol at $25^{\circ} \mathrm{C}$. Scan rate is $50 \mathrm{mV} / \mathrm{s}$. catalytic activity (as shown in Fig. 4(g)). The catalytic properties could also be affected by other factors such as the catalyst material loading amount, impurities, and the alloying element used $(\mathrm{Cu}, \mathrm{Pt}, \mathrm{Au}, \mathrm{Ni})$ [34,37-39]. These issues will be studied in our future work.

\section{Conclusions}

In conclusion, we present a method to fabricate porous Pd bulks with high porosity and a hierarchical pore structure. First, PdAl alloy composites were produced by SPS sintering of PdAl MA powders with $\mathrm{NaCl}$ particles as spacer materials. The $\mathrm{NaCl}$ particles were then dissolved to produce larger pores of tens micrometers. Finally, nanopores were created by dealloying the PdAl alloy. The resultant porous Pd bulk samples showed a high surface area of $54 \mathrm{~m}^{2} / \mathrm{g}$, as well as a compression strength of $\sim 0.5 \mathrm{MPa}$. Electrochemical measurements were performed to evaluate the electrocatalytic properties of the porous Pd bulk samples, indicating good potential for applications in direct ethanol fuel cells.

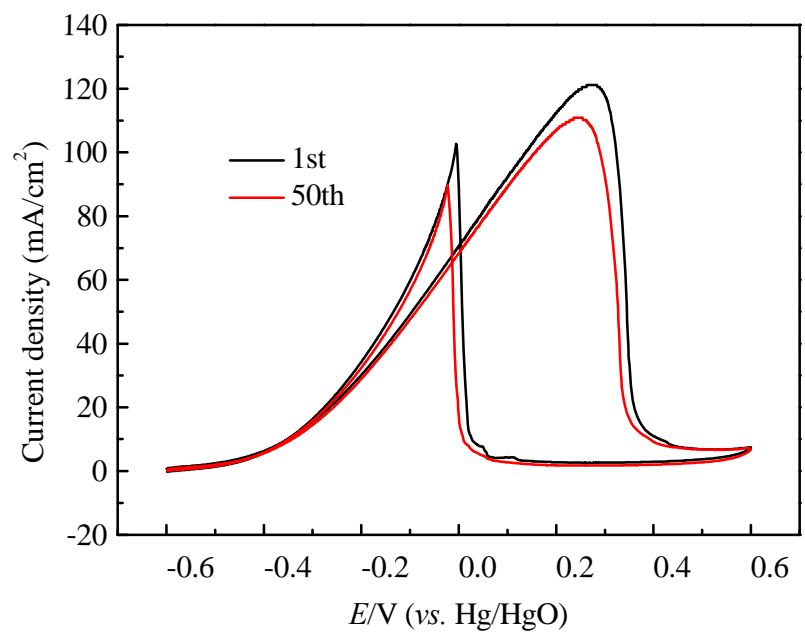

Fig. 10. CV curves of porous Pd electrode in $1 \mathrm{~mol} / \mathrm{L} \mathrm{KOH}$ and $2 \mathrm{~mol} / \mathrm{L}$ ethanol solution at $25^{\circ} \mathrm{C}$. Scan rate is $50 \mathrm{mV} / \mathrm{s}$. 


\section{References}

[1] M. Hakamada, H. Nakano, T. Furukawa, M. Takahashi, M. Mabuchi, J. Phys. Chem. C, 2010, 114, 868-873.

[2] S. Fukada, H. Fujiwara, J. Chromatogr. A, 2000, 898, 125-131.

[3] D. Ciuparu, M. R. Lyubovsky, E. Altman, L. D. Pfefferle, A. Datye, Catal. Rev. Sci. Eng., 2002, 44, 593-649.

[4] Z. X. Liang, T. S. Zhao, J. B. Xu, L. D. Zhu, Electrochim. Acta, 2009, 54, 2203-2208.

[5] Y. J. Huang, X. C. Zhou, J. H. Liao, C. P. Liu, T. H. Lu, W. Xing, Electrochem. Commun., 2008, 10, 621-624.

[6] Y. W. Lee, S. B. Han, K. W. Park, Electrochem. Commun., 2009, 11, 1968-1971.

[7] C. Y. An, K. Zhuo, W. J. Kim, C. H. Chung, Sen. Actua. B, 2015, 213 329-333.

[8] J. B. Xi, Y. Zhang, N. Wang, L. Wang, Z. Y. Zhang, F. Xiao, S. Wang, ACS Appl. Mater. Interf., 2015, 7, 5583-5590.

[9] J. B. Xi, C. Y. Xie, Y. Zhang, L. Wang, J. Xiao, X. M. Duan, J. H. Ren, F. Xiao, S. Wang, ACS Appl. Mater. Interf., 2016, 8, 22563-22573.

[10] B. C. Enger, R. Lö deng, A. Holmen, Appl. Catal. A, 2008, 346, 1-27.

[11] R. F. Hicks, H. H. Qi, M. L. Young, R. G. Lee, J. Catal., 1990, 122, 280-294.

[12] J. Nilsson, P. A. Carlsson, S. Fouladvand, N. M. Martin, J. Gustafson, M. A. Newton, E. Lundgren, H. Grönbeck, M. Skoglundh, ACS Catal., 2015, 5, 2481-2489.

[13] H. Fujiwara, S. Fukada, S. B. B. Mohamad, M. Nishikawa, J. Nucl. Sci. Technol., 2000, 37, 724-726.

[14] C. Bianchini, P. K. Shen, Chem. Rev., 2009, 109, 4183-4206.

[15] M. Hakamada, M. Mabuchi, J. Alloy. Compd., 2009, 479 326-329.

[16] Z. Qi, J. Weissmüller, ACS nano, 2013, 7, 5948-5954.

[17] M. E. Cox, D.C. Dunand, Mater. Sci. Eng. A-Struct., 2011, 528, 2401-2406.
[18] H. M. Duan, Q. Hao, C. X. Xu, J. Power Sources, 2015, 280, 483-490.

[19] M. Li, Y. Liu, G. D. Lu, J. W. Ye, J. Li, M. J. Tu, Int. J. Hydrogen Energy, 2007, 32, 5033-5038.

[20] J. Erlebacher, M. J. Aziz, A. Karma, N. Dimitrov, K. Sieradzki, Nature, 2001, 410, 450-453.

[21] J. Erlebacher, K. Sieradzki, Scripta Mater., 2003, 49, 991-996.

[22] M. Hakamada, M. Mabuchi, Mater. Trans., 2009, 50, 431-435.

[23] Z. H. Zhang, C. Zhang, J. Z. Sun, T. Y. Kou, Q. G. Bai, Y. Wang, Y. Ding, J. Mater. Chem. A, 2013, 1, 3620-3628.

[24] D. T. Jiang, D. M. Hulbert, J. D. Kuntz, U. Anselmi-Tamburini, A. K. Mukherjee, Mater. Sci. Eng. A-Struct., 2007, 463, 89-93.

[25] Z. A. Munir, U. Anselmi-Tamburini, M. Ohyanagi, J. Mater. Sci., 2006, 41, 763-777.

[26] Q. Q. Kong, L. X. Lian, Y. Liu, J. Zhang, Mater. Manuf. Process., 2014, 29, 1232-1236.

[27] Q. Q. Kong, L. X. Lian, Y. Liu, J. Zhang, L. Wang, W. Feng, Microporous Mesoporous Mater., 2015, 208, 152-159.

[28] G. Aldica, V. Khodash, P. Badica, J. R. Groza, J. Optoelectron. Adv. Mater., 2007, 9, 3863-3870.

[29] X. Y. Song, X. M. Liu, J. X. Zhang, J. Am. Ceram. Soc., 2006, 89, 494-500.

[30] R. Chaim, Mater. Sci. Eng. A, 2007, 443, 25-32.

[31] N. Toyofuku, T. Kuramoto, T. Imai, M. Ohyanagi, Z. A. Munir, J. Mater. Sci., 2012, 47, 2201-2205.

[32] M. Grdeń, M. Łukaszewski, G. Jerkiewicz, A. Czerwiński, Electrochim. Acta, 2008, 53, 7583-7598.

[33] X. G. Wang, W. M. Wang, Z. Qi, C. C. Zhao, H. Ji, Z. H. Zhang, Electrochem. Commun., 2009, 11, 1896-1899.

[34] X. G. Wang, W. M. Wang, Z. Qi, C. C. Zhao, H. Ji, Z. H. Zhang, J. Power Sources, 2010, 195, 6740-6747.

[35] W. Q. Zhou, C. Y. Zhai, Y. K. Du, J. K. Xu, P. Yang, Int. J. Hydrogen Energy, 2009, 34, 9316-9323.

\section{Graphical Abstract}

Chin. J. Catal., 2017, 38: 1038-1044 doi: 10.1016/S1872-2067(17)62780-3

Fabrication, characterization and electrochemical properties of porous palladium bulk samples with high porosity and hierarchical pore structure

Qingquan Kong, Wei Feng*, Xiaodong Zhu, Jing Zhang, Chenghua Sun*

Chengdu University, China; Sichuan University, China; Monash University, Australia
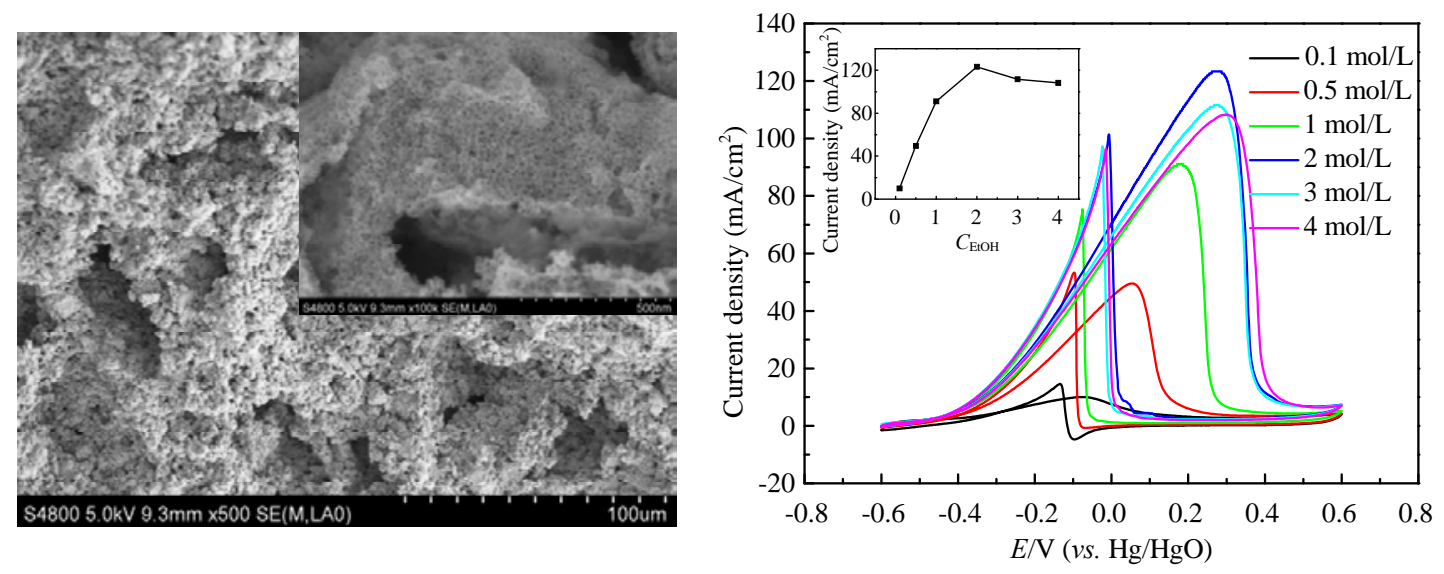

Porous Pd bulks, prepared by salt powder replication combined with a dealloying, show a hierarchical pore structure and high porosity, as well as good ethanol electrochemical oxidation ability. 
[36] Z. P. Sun, X. G. Zhang, Y. Y. Liang, H. L. Li, J. Power Sources, 2009, 191, 366-370.

[37] Z. H. Dan, F. X. Qin, T. Wada, S. I. Yamaura, G. Q. Xie, Y. Sugawara, I. Muto, A. Makino, N. Hara, Electrochim. Acta, 2013, 108, 512-519.
[38] L. Y. Chen, H. Guo, T. Fujita, A. Hirata, W. Zhang, A. Inoue, M. W. Chen, Adv. Funct. Mater., 2011, 21, 4364-4370.

[39] C.X. Xu, A.H. Liu, H. J. Qiu, Y.Q. Liu, Electrochem. Commun., 2011, $13,766-769$.

\title{
兼具高孔隙率和梯度孔隙结构的多孔钯块材的制备、表征及其电化学性能研究
}

\author{
孔清泉 ${ }^{\mathrm{a}}$, 冯 威, ${ }^{\mathrm{a},}$, 朱晓东 ${ }^{\mathrm{a}}$, 张 靖, 孙成华 ${ }^{\mathrm{c}, \#}$ \\ a成都大学机械工程学院, 四川成都610106, 中国 \\ $\mathrm{b}^{\mathrm{U}}$ 四川大学材料科学与工程学院, 四川成都610065, 中国 \\ c澳大利亚莫纳什大学化学学院理学院, 克莱顿VIC3800, 澳大利亚
}

摘要: 钯材料广泛用于氢同位素储存和分离、催化和传感等领域. 传统的负载钯催化材料具有优异的乙醇和甲醇等电化学 催化氧化性能. 除此之外, 负载钯催化材料还具有优异的甲烷催化燃烧性能. 然而, 很多研究显示负载钯催化材料存在很 多不足, 例如在工程应用过程中不稳定, 纳米颗粒会发生聚集和长大, 进而引起材料性能急剧下降等. 不同于钯片、海绵钯 粉末和负载钯催化材料, 多孔钯具有三维连通的孔隙结构, 可避免团聚现象的发生. 同时, 多孔钯还具有一些特殊的物理 化学性能. 研究表明, 梯度孔隙结构是一种高效的电化学催化结构. 因而近年来很多研究者都致力于探索具有高孔隙率和 梯度孔隙结构多孔钯块材的制备方法. 已有的研究包括造孔剂法和模板法等, 但上述方法制得的多孔钯块材均存在比表 面积低或难以获得块体材料缺点.

我们研究组发展了一种制备兼具高孔隙率和梯度孔隙结构的多孔钯块材的新方法. 即通过以一定粒度的NaCl颗粒作 为造孔剂放电等离子烧结制备PdAl合金复合块材, 然后通过去离子水溶解获得多孔PdAI合金, 最后经过在盐酸溶液中去合 金化得到具有数十微米的宏观大孔和约 10 纳米的纳米孔等梯度孔隙结构的多孔钯块材. 当造孔剂添加量为 $20 \mathrm{vol} . \%$, 制 得了孔隙率高达 $88 \%$ 且完整的多孔钯块材. 对该多孔钯块材的力学性能进行了测试, 其压缩强度为 0.5 MPa. 对该块材进行 氮吸附测试, 测试结果显示其比表面积达到 $54 \mathrm{~m}^{2} / \mathrm{g}$. 我们进一步对该多孔钯块材的乙醇电化学催化氧化性能进行了研究. 对不同扫描速度下多孔钯块材在 $\mathrm{KOH}(1 \mathrm{~mol} / \mathrm{L})+$ 乙醇 $(0.8 \mathrm{~mol} / \mathrm{L})$ 溶液中电催化活性进行分析. 随着扫描速率从 $10 \mathrm{mV} / \mathrm{s}$ 提 高到 $50 \mathrm{mV} / \mathrm{s}$, 正扫描峰电流密度也逐渐提高, 且峰电位向正电位方向移动. 对峰电流密度和扫描速率的平方根进行拟合, 发现它们之间存在明显的线性关系, 表明该电催化氧化行为是一个受扩散控制的过程. 随着溶液中乙醇浓度不断增加, 正 扫描方向乙醇氧化峰的峰电流呈现出先增大后减小的趋势. 这是因为乙醇基和羟基在钯表面的竞争性吸附造成的. 当乙 醇浓度较高时, 乙醇基会占据钯表面大量的活性位, 从而阻碍和抑制羟基的吸附. 此时, 羊基在钯表面的吸附成为电氧化 反应的控制因素. 因此, 只有选择合适的乙醇浓度, 才能更好地发挥材料的电催化性能. 当乙醇浓度为 $2 \mathrm{~mol} / \mathrm{L}$ 时, 峰电流 最大, 达到 $120 \mathrm{~mA} / \mathrm{cm}^{2}$, 表明多孔钯块材具有优异的电催化性能, 这与该材料的梯度孔隙结构、高比表面积和高孔隙率密切 相关. 进一步对多孔钯块材的催化稳定性进行研究. 该多孔钯块材显示出了优异的催化稳定性, 当经过50次循环后, 乙醇 氧化峰的峰电流仅下降到 $110 \mathrm{~mA} / \mathrm{cm}^{2}$.

关键词: 钯; 梯度孔隙结构; 电催化; 乙醇氧化; 放电等离子烧结

收稿日期: 2016-11-30. 接受日期: 2017-01-05. 出版日期: 2017-06-05.

*通讯联系人. 电话/传真: (028)84616169; 电子信箱: 50919808@qq.com

\#通讯联系人. 电话: +61-3-99029916; 传真: +61-3-99054597; 电子信箱: Chenghua.Sun@monash.edu

基金来源：国家自然科学基金(11572057), 成都大学校基金重点项目(2080516030).

本文的英文电子版由Elsevier出版社在ScienceDirect上出版(http://www.sciencedirect.com/science/journal/18722067). 